\title{
An Essay on the Ontological Foundations and Psychological Realization of Forgetting
}

\author{
Stan B. Klein \\ University of California at Santa Barbara
}

\begin{abstract}
I argue that appreciation of the phenomenon of forgetting requires serious attention to its origins and place in nature. This, in turn, necessitates metaphysical inquiry as well as empirical backing - a combination likely to be eschewed by psychological orthodoxy. But, if we hope to avoid the conceptual vacuity that characterizes too much of contemporary psychological inquiry (e.g., Klein, 2012, 2014a, 2015a, 2016a), a "big picture" approach to phenomena of interest is essential. Adopting this investigative posture turns the "received view" of the relation between remembering and forgetting on its head: Rather than treated as the result of breakdowns and responses to the limitations of biologically engineered systems of remembering, forgetting is accorded elevated status as the driving force behind the evolution of organic systems of information retention.
\end{abstract}

Keywords: forgetting, remembering, sentience, temporality, change

Ignoring the origin of things is always a risky matter. It is even more risky in an effort that purports to explain mental events. But that is what has happened in much of the history of psychology and the philosophy of mind. (Edelman, 1992, p. 33)

What is forgetting? Although numerous psychological and philosophical treatments have been on display for over 100 years, these efforts have been trained almost exclusively on explication of the mechanisms of forgetting, not on its nature (for review, see Wixted, 2004).

In this article, I attempt to redress this lacuna. It is my firm belief that one must know what it is one is dealing with prior to attempting to elucidate the specifics (e.g., mechanism, context, and function). But to do so requires more than a definition. We need to position the phenomenon in the natural world - to map, as best we can, its origins, location, and interrelations

This article was published Online First June 6, 2019.

I'd like to thank Ray Tallis, Alba Papa-Grimaldi and Monima Chadha for their expertise and generosity.

Correspondence concerning this article should be addressed to (D) Stan B. Klein, Department Psychological and Brain Sciences, University of California at Santa Barbara, 551 Ucen Road, Santa Barbara, CA 93106. E-mail: klein@psych.ucsb.edu within the totality of those things we take to constitute reality. The specifics come later.

In this article I draw on the disciplines of psychology, philosophy, biology, and evolution in an attempt to better situate forgetting within the variegated mosaic that constitutes reality. Based on my analysis, I conclude that forgetting assumes two distinct, but deeply interwoven forms: (a) a presentient instantiation (i.e., physical forgetting) reflecting an object's transition from existence in the present to ontological oblivion in the past and (b) an experiential form (i.e., psychological forgetting), which is the normative outcome of evolution's "solution" to problems faced by sentient beings in consequence of physical forgetting. Seen this way, forgetting is accorded an ontological primacy denied it by contemporary treatments that view forgetting as a shortcoming of biological systems tasked with the preservation of information acquired by an organism within its own lifetime (i.e., ontogenetically).

Because my approach has a clear affiliation with metaphysics, it will be dismissed by some (many?) readers. This is unfortunate. As I survey the psychological landscape from the perspective of a person who has been concerned about the conceptual limitations of our discipline for over 35 years (e.g., Klein, 2012, 
2014a, 2015a, 2016a), I increasingly have been convinced that real progress requires we step back from our empirical frenzy and make a concerted effort to devote serious and sustained attention to (at least some of) the big questions.

In what follows, I make the case for the need to (a) consider forgetting in the fullness in which it is realized in both the physical and experiential aspects of reality and (b) show how appreciation of the construct requires we use all the tools currently available — not just those beholden to a particular discipline. Our methods must be fitted to phenomenon, not phenomenon to method.

\section{Reality, Change, and Time}

Everything flows and nothing stays. (Heraclitus, fragment W20; cited in Brann, 2011, p. 96)

The thesis that "all things are in flux" can be traced to Pre-Socratic Greek antiquity (c. late 6th or early 5th century BCE; e.g., Cornford, 1941, 1957; Kirk, Raven, \& Schofield, 1983). The protagonists divide into two camps (which continue to shape Western debate about the nature of reality; e.g., Papa-Grimaldi, 1998; Toulman \& Goodfield, 1965) distinguished primarily by their metaphysical commitmentsthat is, those who posit change as the nature of reality, and those who regard change as the appearance of an unchanging reality that lays behind it.

The former view-often attributed to ideas culled from the fragmentary remains of the writings of Heraclites (e.g., Brann, 2011; Geldard, 2000)-contends that change is the essential nature of reality. We may believe the world consists in stable objects, but in actuality objects ${ }^{1}$ (and their relations; i.e., events) are in a continual state of flux.

The Eleatics (e.g., Parmenides) recognized change as well, but restricted its purview to aspects of reality accessible to sensory organs (i.e., the physical world). On their view, change is the appearance of motion derived from unchanging, eternal forms that transcend what is accessible to experience (e.g., Cornford, 1957; Geldard, 2007; de Vivar, 2006).

It is important to note that despite differences in assignment of ontological status, both camps accord change a central role in the physical world (interestingly, an essential teaching of Buddhism is the doctrine of Impermanence- the idea that all things, without exception, undergo continual change; e.g., Albahari, 2006; Harvey, 2012; Siderits, 2019). Those championing the Heraclitean perspective hold that all reality is in an unceasing state of flux. Consequently, constituents of the whole (e.g., the physical world) must, of logical necessity, also be in constant motion.

The Eleatic school, in contrast, acknowledges change in the physical world, but argues that change, though derived from reality, is not part of reality per se. However, any account of reality that fails to make room for "appearance" opens itself to serious objections (e.g., Broad, 1925; Dewey, 1958; Klein, 2014a; Meixner, 2008; Plato, 2002; Strawson, 2009; Wallace, 2003). Appearances are experiences, and experiences are happenings realized in a subcategory of physical objects (i.e., the brains of sentient creatures $^{2}$ ).

\section{A Note on the Word "Real" and Claims About Reality}

The question of whether some $\mathrm{X}$ is real presupposes that $\mathrm{X}$ has ontological status-for example, as real, imaginary, and so forth. An appearance has the same mode of being as any mental image (genuine or illusory) and thus is real in the same sense. As Earle noted, "the image or pure datum which the productive imagination forms is not anything imaginary itself. It is actual and a present determination of any sensorium" (Earle, 1955, p. 146). Appearances are counted among the experiential aspects of reality (e.g., Broad, 1925; Crane, 2013;

\footnotetext{
${ }^{1}$ By "objects," I refer to particles, their groupings and relations, characterized by an ontological essence that renders them independent of the descriptions they are given (i.e., natural kinds; e.g., Quine, 1969). Although not exhaustive of reality (e.g., experiential aspects of reality), they are necessary constituents.

${ }^{2}$ Sentience is taken to consist in an internal state in which information-typically, though not necessarily, about the environment-comes to have a subjective feel or qualia (e.g., Nagel, 1974). It is useful to discriminate sentience from sensing. An organism may have the capacity to make sensory-based discriminations absent any phenomenological character (e.g., most plant life can respond to at least some external stimuli. But it is unlikely they have an accompanying subjective experience of the stimulus). Sensing is more highly developed in animals than in plants, reflecting processing requirements necessitated by motility.
} 
Harris, 1988; Klein, 2012, 2014a; Strawson, 2009). ${ }^{3,4}$

The Eleatic postulate that "appearance" is illusory and thus cannot be "real" continues to enjoy wide currency among contemporary psychologists (for reviews, see Klein, 2012, 2014a, 2016a). Much of this appeal, I believe, trades on a failure to appreciate two different senses of the word "real." An appearance is "real" in the first sense when the word signifies that some $X$ is what it seems to be. For instance, the appearance of X (e.g., as a Rolex watch) is "real" if it can be shown that $\mathrm{X}$ is a genuine exemplar of the category "Rolex watches." Conversely, the Müller-Lyer illusion-in which two line segments of objectively equal measure appear to differ in size as a function of the visual context in which they are embedded-is "unreal" in consequence of portraying a state of affairs demonstrably untrue.

In its second sense (the one I use in this article), the appearance of $\mathrm{X}$ is "real" if and only if it is isomorphic with an aspect of nature that exists independent of any categorizations or descriptions it may receive (e.g., Hacking, 1992; Klein, 2018). Appearances (whether illusory or not) are actual events taking place in actual objects (i.e., sentient beings). As such, they are woven into the fabric of reality (Note: On this view, the material monist attempt to maintain metaphysical hegemony by dismissing subjective experience as "mere appearance" is self-refuting).

In short, the question of whether an appearance is a veridical portrayal of a datum (e.g., a Rolex watch) is entirely separate from whether an appearance is part of reality. Although our interpretation of an appearance may be inaccurate, we cannot be mistaken in claiming that appearance, per se, exists as an aspect of reality. 5

\section{Does an Object Remain a Part of Physical Reality When It Becomes Past?}

In what follows, I adopt the widely held view (though not without critics; e.g., Barbour, 2000; McTaggart, 1908; Rochelle, 1998) that objects and events can be situated within a tripartite classification of time as past, present, or future. By this scheme (often referred to as McTaggart's A-Series), the temporal identity of an object varies as a function of its location within the temporal manifold: Objects that once were future will become present and what is present will recede into the past.

It is not my intention to offer a knock-down argument for or against the existence of an object as a function of its temporal identity. I cannot do so and, as best I can tell, neither can anyone else. Nor is it my goal to address all of the philosophical positions that have been marshaled in support or refutation of this ontological thesis (i.e., the reality of an object varies as a function of its temporal position). ${ }^{6}$ Treatment would take us far afield, and I seriously doubt a satisfactory resolution could reasonably be expected. Suffice it to say that, to date, there are no unassailable facts about the ontological status of objects in time.

\footnotetext{
${ }^{3}$ On some reckonings (e.g., Plato, 2002), experiential reality occupies a lower level within a hierarchy of gradations of reality - though not all abide by this assertion of metaphysical inferiority (e.g., Berkeley, 1710/2003; Bohm, 1980; Dewey, 1958; Meixner, 2008; Nagel, 2012; Popper, 1994; Wallace, 2003).

${ }^{4}$ The Eleatic view of change as "mere appearance" implies the existence of a sentience for whom the appearance appears. On the other hand, the idea that prior to the emergence of sentient beings physical reality existed in a state of perpetual stasis is completely at odds with what is known about the evolution of the universe (e.g., Guth, 1997; Jeans, 1943). Although these seemingly disjunctive implications cannot easily be reconciled, rather than ignore the Eleatics I view presentient change (whether real or apparent) as a necessary condition of physical, but not transcendental, reality.

${ }^{5}$ Dewey (1958) made a persuasive case for the reality of appearance: Reality
}

is what existence would be if our reasonably justified
preferences were so completely established in nature as
to exhaust and define its entire being . . . what is left
over (and since trouble, struggle, conflict and error still
empirically exist, something is left over), being ex-
cluded by definition from full reality is assigned a
lower grade or order of being . . . an order variously
called illusion, mortal mind or the merely empirical
against what truly is ... . we have two separate realms
of being ... a classificatory device has been introduced
by which the two traits have been torn apart, one of
them being labeled reality and the other appearance. (p.
54 , emphasis in original)

${ }^{6}$ For the interested reader, contemporary treatments of this thesis can be found in the work of Barbour (2000), Gold (1967), Loizou (1986), Lockwood (2005), McTaggart (1908); McLure (2005), Newton-Smith (1980), Rochelle (1998), Seddon (1987), Tallis (2017), Turetzky (1998), Whitrow (1980), and Yourgrau (2005). 
What I will argue is that on arrival in the past, an object stops being a part of physical reality (e.g., Saint Augustine of Hippo, 1997; Coope, 2005; Hussey, 1993; Kant, 1998; Lieb, 1991; Mead, 2002; Turetzky, 1998; Whitehead, 1929; but see Barbour, 2000; Loizou, 1986). There are a number of ways the case can be made. In keeping with the theme of this section-that is, "change in relation to reality"-I offer the following:

1. Physical reality consists in its entirety of objects in a continual state of real or apparent change (cf., Heraclitus, Parmenides, Plato).

2. Change takes place in the present (e.g., Coope, 2005; Mead, 2002; Tallis, 2008). ${ }^{7}$

3 . On retreating from the present, an object ceases to undergo further change (e.g., Fischer, 1994; Lieb, 1991; Seddon, 1987).

4. Once past, an object falls into ontological oblivion (Points 1 and 3).

By this account, on passing from present to past an object is rendered incapable of change. Because change is a necessary condition for physical existence, once past, an object forfeits its claim to being part of physical reality (this loss of being is consistent with the conservations laws of physics).

In the next section I argue that the past, having no members, either is nonexistent or, if it "exists," does so as an empty set (i.e., a set containing no elements). ${ }^{8}$ In support, I first examine the present and future branches of the A-Series. After showing that both have a legitimate claim to being temporal modes of reality, I argue that the same criteria applied to the past show it to be a temporal chimera.

\section{Past, Present, and Future as Temporal Modalities in the Presentient World}

Although there is considerable agreement that the present is a temporal mode of reality (e.g., Hussey, 1993; Klein, 2013; Lieb, 1991; Le Poidevin, 2003; Mead, 2002; Seddon, 1987; Turetzky, 1998; Whitehead, 1929), the status of the past and future has generated considerable debate (e.g., Faye, 1989; Gallagher, 1998; Harris, 1988; Loizou, 1986; McTaggart, 1908; Newton-Smith, 1980; Rochelle, 1998). Whatever the ultimate solution, I believe such ques- tions most fruitfully are pursued from the Aristotelian perspective that facts about time ultimately are reducible facts about the behavior of objects in time (e.g., Coope, 2005; Harris, 1988; Hussey, 1993). From this vantage point, questions about tensed reality amount to whether change is realized in a particular temporal mode. ${ }^{9,10}$

To determine of any object $\mathrm{X}$ that it is changing (at least) two conditions must be met. First, $\mathrm{X}$ currently must be undergoing some activity. Second, there is some endpoint toward which this activity is directed (e.g., Kant, 1998). Change thus assumes a connection between the object of change and that into which it changes. Seen this way, change occurs in a continuum consisting in two distinguishable modes-it extends forward from the present toward its continuation in the future.

Both formal and phenomenological analyses of the present reveal it to consist in an endless succession of "nows" transitioning (virtually instantaneously) to "nexts": What is present is inextricably entangled with what will be present (e.g., Dolev, 2007; Faye, 1989; Harris, 1988; Husserl, 1964; Klein, 2013; Lieb, 1991; Loizou, 1986; Rochelle, 1998; Seddon, 1987). The present and future can be likened to the intersection on a Venn diagram where an objects' potential for and realization of change overlap.

One may take issue with this analysis, arguing that what "will be" is possibility rather than reality. But a possibility is not nothing. It is something. And that something is determinate, grounded in the determinate character of the existent (e.g., Earle, 1955; Harris, 1988; Lieb, 1991). As Earle (1955, p. 149) observed, what "will be" is inherently part of "the actual be-

\footnotetext{
${ }^{7}$ There also is an argument to be made (see the next section) that change extends into the future (e.g., Kant, 1998).

${ }^{8}$ Whether the past is taken to be unreal, or real but devoid of content, makes little difference to my thesis that prior to the appearance of sentient beings, the past had no participatory role in physical reality.

${ }^{9}$ A reduction, in the sense used here, is an explanation of facts of one kind in terms of facts of another kind. In the present case, facts about temporal modality are understood in terms of facts about the behavior of objects.

${ }^{10}$ Whether the reality of time is reducible to facts about objects in time is a question of longstanding interest to theoreticians concerned with whether there can be time absent change. Discussions can be found in Coope (2005) and Newton-Smith (1980).
} 
cause it is the possibility of the actual, what is, and not of nothing. . . the possibilities of something are also something." Taken this way, the present and future both qualify as modes of temporal reality in virtue being parts of a shared activity. $^{11}$

The past, like the future, is conterminous with the present (e.g., Dolev, 2007; Gallagher, 1998; Harris, 1988; Husserl, 1964; Lieb, 1991; Seddon, 1987). However, unlike the future, an object no longer present has relinquished its claim to physical reality (see previous section). Having no members, the past cannot host changeactual or apparent (e.g., Dolev, 2007; Lieb, 1991; Mead, 2002; Seddon, 1987). It is disqualified as a mode of temporal reality (but see Newton-Smith, 1980, for a dissenting opinion).

In sum, the fruits of change are sown in the future, realized in the present, and finalized in the past (where finalization signifies stasis). Given that the relation between time and reality ultimately are reducible to whether change is realized in a particular mode of temporality (e.g., Coope, 2005; Hussey, 1993), this suggests that physical reality is restricted to the "now and the next." What happened "before" is frozen into nonexistence. ${ }^{12}$ The presentient past is nothing, and a nothing cannot refer to something (a subtle, but very important, perspective to emerge from this analysis is that physical reality moves toward the future, not away from the past).

\section{A Brief Summing Up: The Nature of Forgetting in Presentient Reality}

Presentient reality consists in physical objects undergoing continual change. Change reaches forward from the present to its continuance in the future. It makes no reference to its origins. Indeed, no reference can be made: Once change has been actualized, the object enters a state of stasis and thus concedes any claim to physical reality. What once was now is past and what is past is no more.

Expressed in terms of temporal modality, all that is physically real is real in "a now extending into a next." On receding from the present, an object relinquishes its status as a thing, event, or a possibility. This ontological elimination signifies the all-abiding, eternal loss of objects that once were elements of reality. Taken this way, the past can be seen as the perpetual amnestic state of physical reality: Presentient physical reality continually and completely forgets itself.

One might take issue with the claim that the past has no purchase on physical reality by arguing that surviving records (e.g., geological strata, ${ }^{13}$ fossilized remains, growth rings) are reality's recognition of the past as the formative background of current change. But records exist only in the present. To infer that what is present is a record of what once was requires a sentience capable of making that inductive leap.

\section{Sentience and the Problem of Knowledge}

Our knowledge ${ }^{14}$ of the physical world depends - wholly or in combination with a priori principles (Kant, 1998) — on our experience of the objects with which it is populated (e.g., Broad, 1925; Russell, 1912/1999, 1913/1992; Tallis, 2008). But, to serve as the basis for knowledge, an object must appear sufficiently consistent to permit its identification and reidentification (e.g., Brennan, 1988; Mead, 2002; Sider, 2001). We must be able to attribute properties (e.g., size, shape, color, etc.) in virtue of which the object acquires its identity.

Sentient beings are bathed in continual flux. This creates a problem for creatures whose evolutionary viability depends, in large part, on the capacity to acquire knowledge of their surroundings. It is very difficult to assign individuating properties to a moving target. It is impossible to do so for objects that have entered ontological oblivion.

11 That the future consists in possibility rather than actuality (e.g., Lieb, 1991; Lockwood, 2005; Tallis, 2008) does not undermine its claim to temporal existence. Only one possibility will be actualized in the present. So long as that actualization is not inconsistent with change currently taking place, future indeterminacy is an epistemological-not an ontological-problem.

${ }^{12}$ Although the notion of "creating a non-existent" sounds like an oxymoron, it is not. For instance, the thought of a unicorn is real even if unicorns are not (for discussion, see Crane, 2013).

${ }^{13}$ A geological stratum is a layer of rock with internal characteristics that distinguishes it from contiguous layers. The layers typically are situated one upon another and are assumed to have been positioned over time by natural processes.

${ }^{14}$ In this article, the term knowledge is not to be taken in its philosophical sense as true, justified belief. Rather, it is used to denote any ontologically acquired information operated on by conscious or unconscious processes in the service of thought, decisions and behavior. 
Put differently, a sentient creature's ability to know about and engage with objects in its environment is a direct function of an object's expectedness (e.g., Spencer Brown, 1957). It only is when an object does what we expect it to do that it becomes a knowable aspect of reality. Expectedness, in turn, requires that what we observe does not change- or changes very slowly (where "slowly" refers to the temporal resolution of our sensory systems).

But, expectedness is inversely related to rate of change. If something - a rock, a rat, a person, a planet-changes too rapidly, or too often, we find it difficult to develop expectations. In consequence, the object's status as an identifiable (and potentially predictable) part of the perceptible world is undermined.

For example, if a person changed her size, shape, color, physical characteristics, psychological dispositions, and so forth each time we encountered her, we would be unable to name, much less know her. In the absence of such knowledge, we would be unable to formulate expectations (e.g., who she is, how she is likely to behave). Our ability to imbue (the appearance of) stasis on objects undergoing continual change allows us to form expectations about their properties and causal potencies. This, in turn, provides us with knowledge of what they are and how they are predisposed to act. However, object fixation is the exclusive province of the past. Accordingly, an organism's opportunity to stabilize sensation paradoxically is limited to those aspects of reality engulfed in ontological amnesia.

These requirements appear incommensurate. Because physical reality is in a state of continual flux, it is only on transitioning to the past that an object acquires the stability required for identification. But the past, in virtue of being fixed, is physically unreal. Therein lies the problem. To permit identification, an object's experienced presentation must be (reasonably) constant. But such uniformity is found only after the object has become past, at which point it no longer is available for identification.

Sentient creatures face a paradox. If reality is to be known, the knower must find a way to stabilize the objects of the physical world. But, objects in stasis no longer are part of physical reality and thus no longer available to be known. What was needed was a means of experientially stabilizing the objects of physical reality, thereby escaping existential purging attending transition to the past.

\section{Addressing the Problem: A Biological Intervention}

The ability to transform physical flux into relatively stable ${ }^{15}$ mental representations is evolution's answer to this paradox. ${ }^{16}$ In the early phase of organic evolution, sentient creatures had recourse only to rudimentary mechanisms of stimulus stabilization (e.g., perceptual constancies, sensitization, stimulus generalization) to help navigate the chaotic world of sensory variation (e.g., Eccles, 1989; Kaufman, 1974; Mostofsky, 1965; Walsh \& Kulikowski, 1998; Young, 1976). Such mechanisms, being largely reflexive, were not able to support sustained, flexible and tailored engagement with the environment (e.g., Klein, Cosmides, Tooby, \& Chance, 2002).

Remembering ${ }^{17}$ solved this problem by supplying the appropriate neural systems with knowledge for use in coordinating responses to internal and external contingencies. The pri-

\footnotetext{
${ }^{15}$ It is important to recognize that "stabilization," applied to experiential reality, is a relative term. More, remembered contents are not faithful transcriptions of the objects and events that gave rise to them; rather, they are approximate reconstructions that knit past experience with current beliefs, motives, and even external suggestions (e.g., Klein, 2014b). In short, remembering is constructive rather than reproductive. This idea, which is commonplace among modern researchers, traces to work by Münsterberg (1909) and Bartlett (1932).

${ }^{16}$ I acknowledge that my distinction between the flux of the physical and the stability of the sentient reality is an implicit jab at the physical monism of psychological orthodoxy. In Klein (2012, 2014a, 2014c, 2015a, 2016a) I make the case for remaining open to the possibility that "reality" in its fullness is constituted by a plurality of aspects that likely share different ontological commitments (see also Earle, 1955; James, 1909/1996; Meixner, 2005). Perhaps a "finished" physicalism will be capable of explaining the mind without having to treat its subjective aspects as epiphenomenal (e.g., Russell, 1921/1949). But we do not at present know what a fully matured physics might consist in. And, for a number of reasons (e.g., Klein, 2014a, 2016a) we never may. Accordingly, tethering our understanding of mind to a future version of physicalism requires we accept a promissory note with no way of envisaging the conditions of the note.

${ }^{17}$ Throughout this article I will use the word remember rather than memory. Although virtually all academics take the two to be synonyms (Klein, 2018), I draw a sharp distinction: Remembering is the process by which stored knowledge is made available to consciousness. Memory is only one of many potential products of remembering. What separates memory from other mental states (e.g., knowledge, belief, imagination) is that the remembered material is accompanied by an immediate, nonanalytic feeling that my current mental state is coterminous with a state of affairs I experienced in my past. Because little in the present article rides on this distinction, I will not rehearse my reasons for these claims here. For those interested, my arguments can be found in Klein (2015b) or Klein (2018).
} 
mary mechanism by which this is accomplished is consolidation - that is, the progressive neural stabilization of ontogenetically acquired information (e.g., Dudai, 2004; McGaugh, 2000; Nadel \& Moscovitch, 1997; Polster, Nadel, \& Schacter, 1991; Squire \& Alvarez, 1995). By capturing the world of change in representational formats, the organism can know aboutrather than simply be influenced by-its physical surroundings.

But a representational structure, no matter how stable or complex, is little more than a pointless appendage unless accompanied by mechanisms capable of making it available to the right systems at the right times. And this is exactly what a system of remembering accomplishes (for discussion see Klein et al., 2002). Remembering can thus be viewed as the sentient counterweight to physical reality's ontological amnesia (but, as we will see in the next section, remembering creates its own forms of forgetting).

Because mental processes do not leave fossil records, it is difficult, if impossible, to know when remembering was added to the biological tool kit. Some paleontological clues can, however, help guide informed speculation. The origin of vertebrate systems of remembering is hypothesized to date to the Cambrian "explosion" (e.g., Ginsburg \& Jablonka, 2007, 2010). This period, which spanned approximately 25 million years beginning around 545 million years ago, is considered one of the most significant transitions in evolutionary history (e.g., Marshall, 2006; Vallentine, 2004): In a short time (by evolutionary standards) essentially all animal phyla first appear in the fossil records (e.g., Vallentine, 2002).

The cause of the Cambrian "explosion" is the subject of considerable debate (e.g., changes in the oxygenation or temperature of the biotic environment; for discussion, see Marshall, 2006; Vallentine, 2004). One well-regarded theory is that the ecological and morphological diversification during the "explosion" stemmed from a genetic reorganization of the central nervous system that occurred in parallel among several groups of metazoans (e.g., Cabej, 2008; Ginsburg \& Jablonka, 2007).

Of significance for our discussion, this reorganization is hypothesized to have resulted in the development of neural processes capable of supporting nascent forms of remembering (for review, see Ginsburg \& Jablonka, 2007). This made possible numerous behavioral adjustments during an animal's lifetime, which, in turn, set the stage for a variety of survivalrelevant adaptations. Organisms capable of remembering are thus gifted with enormous selective advantages (for discussions, see Boyer, 2009; Klein et al., 2002; Nairne, 2005; Tulving, 2005).

\section{Forgetting as an Aspect of Psychobiological Reality}

Remembering is the sentient realization of a biological system whose organization was shaped by recurrent problems faced in the environment of evolutionary adaptation (e.g., Glenberg, 1997; Klein, 2007, 2013, 2014b; Klein et al., 2002; Nairne, 2005; Sherry \& Schacter, 1987). One useful way to study a biological system is to adopt an adaptationist perspective (e.g., Barkow, Cosmides, \& Tooby, 1992; Cosmides \& Tooby, 1992; Klein et al., 2002). On this account, remembering can be seen as part of an organic machine designed by natural selection to use knowledge acquired in an animal's past to coordinate its behavior in the present and future (e.g., Klein et al., 2002; Klein, 2007, 2016b).

But, like any machine, successful operation involves the complex interplay of finely coordinated parts. Consequently, the architecture supporting remembering is subject to a variety of structural limitations (e.g., inhibition, interference, decay) and real-time vulnerabilities (e.g., componential fatigue, physical insult, psycho-social stress).

More than a century of research has made clear that failure is the normative outcome on tests of retention (e.g., Ballard, 1913; Brown, 1923). For example, in multitrial tests of free recall (e.g., Klein, Loftus, Kihlstrom, \& Aseron, 1989; Tulving, 1964), investigators unfailingly find that items not remembered on one trial may be remembered on another (item gain), whereas items remembered on previous trials may not be remembered on later attempts (item loss). Importantly - with the exception of highly unusual circumstances (e.g., hypermnestic recall; e.g.,Erdelyi, 1984) - item losses exceed gains (for reviews see Payne, 1987; Roediger \& Challis, 1989). 
More generally, a simple tally of "information presented minus information remembered" reveals that in virtually every investigation of "memory,"18 retention failure eclipses (often by a substantial margin) retention success. This disparity is on display in such diverse phenomena as encoding specificity (e.g., Tulving \& Thomson, 1973), mood state dependence (e.g., Bower, 1981), free recall (e.g., Tulving, 1964), repeated reproduction (e.g., Bartlett, 1932), serial position effects (e.g., Murdock, 1962), the temporal gradient of recollection (e.g., Ribot, 1882), the formation of semantic abstractions (e.g., Caramazza, 2000), encoding task variability (e.g., Craik \& Lockhart, 1972), and the method of savings (e.g., Ebbinghaus, 1885/ 1913).

Outside the lab, the gap between remembering and forgetting is even more pronounced (e.g., Brewer, 1994; Neisser, 1981; Rubin, 1996; Thompson et al., 1998). Consider life experience. Most of the information remembered minutes, days, weeks, or months following its occurrence will be lost as life pushes forward. What remains is a mere pittance of what once readily was accessible (e.g., Galton, 1879; Jansari \& Parkin, 1996; Linton, 1975). For example, try to provide a reasonably detailed account of the events that transpired on a particular day during the previous month. Although this likely presented little problem at day's end, the undertaking now is formidable. And it will be even more demanding next month (e.g., Crovitz \& Schiffman, 1974; Thompson, 1982). Cohen (1985) goes so far as to elevate this phenomenon to a general law of remembering: "The longer something has been retained in memory, the less the likelihood that it will be remembered" (p. 253). ${ }^{19}$

In summary, a striking irony about biologically engineered systems for remembering is that their modus operandi, more often than not, is retention failure. Yet, despite this stark asymmetry, psychologists disproportionately focus investigative effort on explicating the system's achievements. Case in point: While hundreds of scholarly volumes have devoted the topic of remembering (many of which inhabit my bookshelves), to date the lone offerings dedicated exclusively to the topic of forgetting consist in one edited volume (Della Sala, 2010) and a single-authored monograph (Draaisma, 2015).

\section{Why the Second Tier Status?}

A principle reason for this neglect is that forgetting typically is seen as symptomatic of imperfections in the design of systems tasked with remembering. This sentiment is clearly articulated by Nairne and Pandeirada (2008, p. 179), who observed that most for academics forgetting is considered "a breakdown in an otherwise efficient mental capacity" (see also Cubelli, 2010; Michaelian, 2011; Roediger, Weinstein, \& Agarwal, 2010; Schacter, 2001). Assuming scholarly effort most profitably is trained on what a machine was designed to accomplish (e.g., Klein, 2014b; Klein et al., 2002), it would seem counterproductive to treat the unwanted residue of a system's vulnerabilities as the primary target of investigative inquiry. And, although system failures are not without theoretic and practical value (e.g., the clinical amnesias; for review, see Rosenbaum, Murphy, \& Rich, 2011), they often are seen as existentially derivative in virtue of being structurally parasitic on mechanisms governing how the system is supposed to operate (but see Freud, 1940).

In short, most investigators accord the phenomenon of forgetting a lower or secondary status. However-as I hope I have made clear-in so doing, scholars unintentionally undercut the very factor that gives their conceptual offerings point and bearing. Rather than a design flaw in a system biologically engineered to counterbalance the persistent loss of physical reality, forgetting was the driving force behind natural selection's "solution" to the problem of change and knowledge. Forgetting is anything but a second-class citizen.

\section{Conclusion and Final Thoughts}

On the view presented here, ontological elimination (i.e., presentient forgetting) is one of the

\footnotetext{
${ }^{18}$ For an explanation of the scare quotes flanking the word memory, see Footnote 17.

${ }^{19}$ Importantly - despite assertions to the contrary (e.g., Frise, 2018) - the evidence makes abundantly clear that forgetting need not, and typical does not, require a concomitant intention to retrieve. In both clinical (e.g., Prigatano \& Schacter, 1991; Talland \& Waugh, 1969) and nonclinical (e.g., Brewer, 1994; Engel, 1999; Neisser, 1981) conditions, forgetting commonly takes the form of a failure to remember things that ordinarily would have been automatically evoked in and by context.
} 
two fundamental modes of physical reality (the other being ontological existence). Indeed, the need to stabilize reality prior to its descent into oblivion was the impetus for the evolution of sentient, carbon-based systems for remembering. (Although not the place for a comprehensive treatment of conceptual parallels, it is worth noting that the "problem of change" is also the crux of Gestalt psychology's view on changing sensations vis a vis perceptual constancies and on learning vis a vis forgetting; e.g., Köhler, 1947.) $)^{20}$

More specifically, forgetting is the loss of that which once had physical and/or psychological presence. In physical reality, forgetting is the irrevocable loss of the objects and their relations in consequence of their recession into the past. In experiential reality, forgetting assumes an additional articulation-the temporary or permanent loss of access to information acquired by naturally selected systems of remembering.

This conception is at odds with prevailing treatments of forgetting as a deficiency in the apparatus of remembering (e.g., Nairne \& Pandeirada, 2008; Schacter, 2001; Tulving, 1974; Underwood, 1966). This deflationary view is nicely captured by Bernecker (2008), who concluded "forgetting can be adequately defined only by way of appeal to the notion of remembering" (p. 27; emphasis added).

My reconceptualization turns this on its head. Rather than seen as the unwelcome byproduct of an organic machine tasked with remembering (while this characterizes some types of forgetting, it is relatively small part of the big picture), forgetting is accorded ontological primacy. It is the aspect of reality that necessitated the evolution of biologically engineered systems designed to minimize its occurrence. But nature's "solutions" seldom, if ever, attain perfection (e.g., Williams, 1966). Ironically, the principle commodity of the mechanisms of retention is forgetting.

Any proposal, no matter how carefully crafted, runs the risk of being an exercise in conceptual hair splitting unless it can be shown to make a positive difference in how we approach our target of inquiry. The possibility thus exists that my revisionary discourse on the ontological status of remembering and forgetting amounts to "a difference that does not make a difference."
Although it is beyond the scope of this article to provide a comprehensive account of the implications of my reconceptualization for the workings of the mind, I do want to briefly discuss its ramifications for recent attempts to habilitate forgetting by treating it as an evolved solution to what commonly is referred to as "information clutter" (e.g., Anderson \& Schooler, 1991; Michaelian, 2011; Nairne \& Pandeirada, 2008; Roediger et al., 2010). The basic idea is that the amount of information in storage generally exceeds its practical functionality (a variant of the "clutter" problem invokes storage limitations, but this assertion lacks both conceptual and empirical warrant). Accordingly, so the argument goes, mechanisms must have evolved to help the organism deal with mental clutter.

The prototypical example is the problem of "where I last left X" (e.g., reading glasses, coffee cup, house keys). Absent a mechanism for updating (e.g., Bjork, 1978) and/or discarding (e.g., Michaelian, 2011) clutter, search engines tasked with accessing task-relevant data would be inundated with information of questionable value (e.g., remembering the previous 20 places I parked my car would be more confusing than beneficial to locating its current location).

Although the benefits of clutter removal seem clear, the idea that evolution designed mechanisms for this purpose is far from compelling. First, identification of an item as "clutter" requires ways for the system to determine which elements in storage are in need of updating or assignment to the scrap heap. How might this be accomplished?

Numerous possibilities have been tendered, including, but not limited to, recency and regularity of use, predictive value, and personal relevance. But each is easily defeasible (e.g., one's social security number or the date of mom's 90th birthday may be have considerable personal value despite lack of recent access; determining predictive import assumes the cooperation of sophisticated mechanisms capable of making stochastic decisions about events that may never transpire).

Because evolutionary adaptations seldom, if ever, are optimal (e.g., the shared opening to the

\footnotetext{
${ }^{20}$ I am grateful to Professor Robert Kunzendorf' for this important observation.
} 
esophagus and trachea in many mammals), perhaps probative indices are better considered heuristic than definitive. Even allowing such latitude, the stubborn fact remains that organisms tend not to expend energy and resources on adaptive solutions to problems whose resolution is inherent in the workings of nature. For example, the existence of gravitational force makes it pointless to evolve mechanisms that enable an organism to maintain contact with terra firma. We can, and do, evolve systems for countering the effects of gravity (e.g., the semicircular ducts of the inner ear evolved to detect rotational movement and maintain balance), but we do not need systems to enable gravitational effects per se.

Forgetting is an unceasing aspect of existence: The vast majority of the knowledge we acquire suffers a common fate-its eventual, often permanent, loss. There is no need to evolve mechanisms to enable its occurrence. One reason that examples of the purported benefits of forgetting seem compelling is because they are cherry picked expressly for that purpose. In point of fact, the locations of most objects we encounter will be forgotten (often much sooner than desired) regardless of whether there is value in so doing.

\section{References}

Albahari, M. (2006). Analytical Buddhism: The twotiered illusion of self. Houndsmills, UK: Palgrave Macmillan. http://dx.doi.org/10.1057/978 0230800540

Anderson, J. R., \& Schooler, L. J. (1991). Reflections of the environment in memory. Psychological Science, 2, 396-408. http://dx.doi.org/10.1111/j .1467-9280.1991.tb00174.x

Ballard, P. B. (1913). Oblivescence and reminiscence. Cambridge, UK: Cambridge University Press.

Barbour, J. (2000). The end of time. New York, NY: Oxford University Press.

Barkow, J. H., Cosmides, L., \& Tooby, J. (1992). The adapted mind: Evolutionary psychology and the generation of culture. New York, NY: Oxford University Press.

Bartlett, F. C. (1932). Remembering. London, UK: Cambridge University Press.

Berkeley, G. (2003). A treatise concerning the principles of human knowledge. Mineola, NY: Dover Publications. (Original work published 1710)
Bernecker, S. (2008). The metaphysics of memory. New York, NY: Springer. http://dx.doi.org/10 .1007/978-1-4020-8220-7

Bjork, R. A. (1978). The updating of human memory. In G. H. Bower (Ed.), The psychology of learning and motivation (Vol. 12, pp. 235-259). New York, NY: Academic Press.

Bohm, D. (1980). Wholeness and the implicate order. London, UK: Routledge \& Kegan Paul.

Bower, G. H. (1981). Mood and memory. American Psychologist, 36, 129-148. http://dx.doi.org/10 .1037/0003-066X.36.2.129

Boyer, P. (2009). What are memories for? Functions of recall in cognition and culture. In P. Boyer \& J. V. Wertsch (Eds.), Memory in mind and culture (pp. 3-28). Cambridge, UK: Cambridge University Press. http://dx.doi.org/10.1017/CBO97 80511626999.002

Brann, E. (2011). The logos of Heraclitus. Philadelphia, PA: Paul Dry Books, Inc.

Brennan, A. (1988). Conditions of identity: A study in identity and survival. Oxford, UK: Oxford University Press.

Brewer, W. F. (1994). Autobiographical memory and survey research. In N. Schwarz \& S. Sudman (Eds.), Autobiographical memory and the validity of retrospective reports (pp. 11-20). New York, NY: Springer-Verlag. http://dx.doi.org/10.1007/ 978-1-4612-2624-6_2

Broad, C. D. (1925). The mind and its place in nature. London, UK: Kegan Paul, Trench, Trubner \& Co., Ltd.

Brown, W. (1923). To what extent is memory measured by a single recall? Journal of Experimental Psychology, 6, 377-385. http://dx.doi.org/10.1037/ h0073877

Cabej, R. N. (2008). Epigenetic principles of evolution. Dumont, NJ: Albanet Publishing.

Caramazza, A. (2000). The organization of conceptual knowledge in the brain. In M. S. Gazzaniga (Ed.), The new cognitive neurosciences (pp. 10371046). Cambridge, MA: MIT Press.

Cohen, R. L. (1985). On the generality of the laws of memory. In L.-G. Nilsson \& T. Archer (Eds.), Perspectives on learning and memory (pp. 247277). Hillsdale, NJ: Erlbaum, Publishers.

Coope, U. (2005). Time of Aristotle: Physics, IV.10_ 14. Oxford, UK: Oxford University Press.

Cornford, F. M. (1941). The Republic of Plato. London, UK: Oxford University Press.

Cornford, F. M. (1957). Plato and Parmenides. New York, NY: The Liberal Arts Press.

Cosmides, L., \& Tooby, J. (1992). Cognitive adaptations for social exchange. In J. Barkow, L. Cosmides, \& J. Tooby (Eds.), The adapted mind: Evolutionary psychology and the generation of culture (pp. 163-228). New York, NY: Oxford University Press. 
Craik, F. I. M., \& Lockhart, R. S. (1972). Levels of processing: A framework for memory research. Journal of Verbal Learning \& Verbal Behavior, 11, 671-684. http://dx.doi.org/10.1016/S00225371(72)80001-X

Crane, T. (2013). The objects of thought. Oxford, UK: Oxford University Press. http://dx.doi.org/10 .1093/acprof:oso/9780199682744.001.0001

Crovitz, H. F., \& Schiffman, H. (1974). Frequency of episodic memories as a function of their age. Bulletin of the Psychonomic Society, 4, 517-518. http://dx.doi.org/10.3758/BF03334277

Cubelli, R. (2010). A new taxonomy of memory and forgetting. In S. Della Sala (Ed.), Forgetting (pp. 35-47). New York, NY: Psychology Press.

Della Sala, S. (2010). Forgetting. New York, NY: Psychology Press. http://dx.doi.org/10.4324/97 80203851647

de Vivar, C. M. R. (2006). Time and necessity in Parmenides. Astoria, NY: Seaburn Publishing Company.

Dewey, J. (1958). Experience and nature. New York, NY: Dover publications, Inc.

Dolev, Y. (2007). Time and realism: Metaphysical and Antimetaphysical perspectives. Cambridge, MA: The MIT Press. http://dx.doi.org/10.7551/ mitpress/7485.001.0001

Draaisma, D. (2015). Forgetting: Myths, perils and compensations. New Haven, CT: Yale University Press. http://dx.doi.org/10.12987/yale/97803 00207286.001 .0001

Dudai, Y. (2004). The neurobiology of consolidations, or, how stable is the engram? Annual Review of Psychology, 55, 51-86. http://dx.doi.org/10 .1146/annurev.psych.55.090902.142050

Earle, W. (1955). Objectivity: An essay on phenomenological ontology. New York, NY: The Noonday Press.

Ebbinghaus, H. (1885/1913). Memory: A contribution to experimental psychology $(\mathrm{H}$. A. Ruger \& C. Bussenius, Trans.). New York, NY: Teacher's College, Columbia University.

Eccles, J. C. (1989). Evolution of the brain: The creation of consciousness. London, UK: Routledge.

Edelman, G. M. (1992). Bright air, brilliant fire: On the matter of the mind. New York, NY: Basic Books.

Engel, S. (1999). Context is everything: The nature of memory. New York, NY: Freeman and Company.

Erdelyi, M. H. (1984). The recovery of unconscious (inacessible) memories: Laboratory studies of hypermnesia. In G. Bower (Ed.), The psychology of learning and motivation (Vol. 18, pp. 95-127). New York, NY: Academic Press.

Faye, J. (1989). The reality of the future. Odense, Denmark: Odense University Press.
Fischer, J. M. (1994). The metaphysics of free will. Malden, MA: Blackwell.

Freud, S. (1940). New introductory lectures of psychoanalysis. London, UK: George Allen \& Unwin.

Frise, M. (2018). Forgetting. In K. Michaelian, D. Debus, \& D. Perrin (Eds.), New directions in the philosophy of memory (pp. 223-240). New York, NY: Routledge. http://dx.doi.org/10.4324/9781 315159591-12

Gallagher, S. (1998). The inordinance of time. Evanston, IL: Northwestern University Press.

Galton, F. (1879). Psychometric experiments. Brain: A Journal of Neurology, 2, 149-162. http://dx.doi .org/10.1093/brain/2.2.149

Geldard, R. (2000). Remembering Heraclitus. Herndon, VA: Lindisfarne Books.

Geldard, R. G. (2007). Parmenides and the way of truth. Rhinebeck, NY: Monkfish Book and Publishing Company.

Ginsburg, S., \& Jablonka, E. (2007). The translation to experience: Limited learning and limited experiencing. Biological Theory, 2, 218-230. http://dx .doi.org/10.1162/biot.2007.2.3.218

Ginsburg, S., \& Jablonka, E. (2010). The evolution of associative learning: A factor in the Cambrian explosion. Journal of Theoretical Biology, 266, 1120. http://dx.doi.org/10.1016/j.jtbi.2010.06.017

Glenberg, A. M. (1997). What memory is for. Behavioral and Brain Sciences, 20, 1-19.

Gold, T. (1967). The nature of time. Ithaca, NY: Cornell University Press.

Guth, A. (1997). The inflationary universe. New York, NY: Addison Wesley.

Hacking, I. (1992). Word-making by kind-making: Child abuse for example. In M. Douglas \& D. Hull (Eds.), How classification works: Nelson Goodman among the social sciences (pp. 180-238). Edinburgh, UK: Edinburgh University Press.

Harris, E. E. (1988). The reality of time. Albany, NY: SUNY Press.

Harvey, P. (2012). An introduction to Buddhism: Teachings, history and practices. Cambridge, UK: Cambridge University Press. http://dx.doi.org/10 .1017/CBO9781139050531

Husserl, E. (1964). The phenomenology of internal time-consciousness. Bloomington: Indiana University Press.

Hussey, E. (1993). Aristotle's physics books III and $I V$. Oxford, UK: New York: Oxford University Press.

James, W. (1909/1996). A pluralistic universe. Lincoln: University of Nebraska Press.

Jansari, A., \& Parkin, A. J. (1996). Things that go bump in your life: Explaining the reminiscence bump in autobiographical memory. Psychology and Aging, 11, 85-91. http://dx.doi.org/10.1037/ 0882-7974.11.1.85 
Jeans, J. (1943). The mysterious universe; New (rev. ed.). New York, NY: The Macmillan Company.

Kant, I. (1998). The Cambridge ed. of the works of Immanuel Kant; Critique of pure reason (P. Guyer \& A. W. Wood, Trans.). New York, NY: Cambridge University Press.

Kaufman, L. (1974). Sight and mind. New York, NY: Oxford University Press. http://dx.doi.org/10 .1097/00006324-197411000-00015

Kirk, G. S., Raven, J. E., \& Schofield, M. (1983). The presocratic philosophers (2nd ed.). Cambridge, UK: Cambridge University Press. http://dx.doi .org/10.1017/CBO9780511813375

Klein, S. B. (2007). Phylogeny and evolution: Implications for understanding the nature of a memory system. In H. L. Roediger, Y. Dudai, \& S. Fitzgerald (Eds.), Science of memory concepts (pp. 377381). New York, NY: Oxford.

Klein, S. B. (2012). The self and its brain. Social Cognition, 30, 474-516. http://dx.doi.org/10.1521/ soco.2012.30.4.474

Klein, S. B. (2013). The complex act of projecting oneself into the future. WIREs Cognitive Science, 4, 63-79. http://dx.doi.org/10.1002/wcs.1210

Klein, S. B. (2014a). The two selves: Their metaphysical commitments and functional independence. New York, NY: Oxford University Press.

Klein, S. B. (2014b). Autonoesis and belief in a personal past: An evolutionary theory of episodic memory indices. Review of Philosophy and Psychology, 5, 427-447. http://dx.doi.org/10.1007/ s13164-014-0181-8

Klein, S. B. (2014c). What can recent replication failures tell us about the theoretical commitments of psychology? Theory \& Psychology, 24, 326338. http://dx.doi.org/10.1177/0959354314529616

Klein, S. B. (2015a). A defense of experiential realism: The need to take phenomenological reality on its own terms in the study of the mind. Psychology of Consciousness Consciousness: Theory, Research, and Practice, 2, 41-56. http://dx.doi.org/ $10.1037 / \mathrm{cns} 0000036$

Klein, S. B. (2015b). What memory is. WIREs Cognitive Science, 6, 1-38. http://dx.doi.org/10.1002/ wcs. 1333

Klein, S. B. (2016a). The unplanned obsolescence of psychological science and an argument for its revival. Psychology of Consciousness Consciousness: Theory, Research, and Practice, 3, 357-379. http://dx.doi.org/10.1037/cns0000079

Klein, S. B. (2016b). Autonoetic consciousness: Reconsidering the role of episodic memory in futureoriented self-projection. The Quarterly Journal of Experimental Psychology, 69, 381-401. http://dx .doi.org/10.1080/17470218.2015.1007150

Klein, S. B. (2018). Remembering with and without memory: A theory of memory and aspects of mind that enable its experience. Psychology of Con- sciousness: Theory, Research, and Practice, 5, 117-130. http://dx.doi.org/10.1037/cns0000142

Klein, S. B., Cosmides, L., Tooby, J., \& Chance, S. (2002). Decisions and the evolution of memory: Multiple systems, multiple functions. Psychological Review, 109, 306-329. http://dx.doi.org/10 .1037/0033-295X.109.2.306

Klein, S. B., Loftus, J., Kihlstrom, J. F., \& Aseron, R. (1989). Effects of item-specific and relational information on hypermnesic recall. Journal of Experimental Psychology: Learning, Memory, and Cognition, 15, 1192-1197. http://dx.doi.org/10 1037/0278-7393.15.6.1192

Köhler, W. (1947). Gestalt psychology: An introduction to new concepts in modern psychology. New York, NY: Liveright.

Le Poidevin, R. (2003). Travels in four dimensions: The enigmas of space and time. Oxford, UK: Oxford University Press.

Lieb, I. C. (1991). Past, present, and future: A philosophical essay about time. Chicago, IL: University of Illinois Press.

Linton, M. (1975). Memory for real-world events. In D. A. Norman \& D. E. Rumelhart (Eds.), Explorations in cognition (pp. 376-404). San Francisco, CA: Freeman.

Lockwood, M. (2005). The labyrinth of time. New York, NY: Oxford University Press.

Loizou, A. (1986). The reality of time. Aldershot, UK: Gower Publishing Co.

Marshall, C. R. (2006). Explaining the Cambrian "explosion" of animals. Annual Review of Earth and Planetary Sciences, 34, 355-384. http://dx.doi .org/10.1146/annurev.earth.33.031504.103001

McGaugh, J. L. (2000). Memory-a century of consolidation. Science, 287, 248-251. http://dx.doi .org/10.1126/science.287.5451.248

McLure, R. (2005). The philosophy of time. New York, NY: Routledge.

McTaggart, J. M. E. (1908). The unreality of time. Mind, 17, 457-474. http://dx.doi.org/10.1093/ mind/XVII.4.457

Mead, G. H. (2002). The philosophy of the present. Amherst, NY: Prometheus Books.

Meixner, U. (2005). Physicalism, dualism and intellectual honesty. Dualism Review, 1, 1-20.

Meixner, U. (2008). The reduction of reductive and non-reductive materialism-and a new start. In A. Antonietti, A. Corradini, \& E. J. Lowe (Eds.), Psycho-physical dualism: An interdisciplinary approach (pp. 143-166). Boulder, CO: Rowman \& Littlefield Publishers, Inc.

Michaelian, K. (2011). The epistemology of forgetting. Erkenntnis, 74, 399-424. http://dx.doi.org/10 .1007/s10670-010-9232-4

Mostofsky, D. J. (1965). Stimulus generalization. Stanford, CA: Stanford University Press. 
Münsterberg, H. (1909). On the witness stand: Essays on psychology and crime. New York, NY: Doubleday.

Murdock, B. B., Jr. (1962). The serial position effect of free recall. Journal of Experimental Psychology, 64, 482-488. http://dx.doi.org/10.1037/h0045106

Nadel, L., \& Moscovitch, M. (1997). Memory consolidation, retrograde amnesia and the hippocampal complex. Current Opinion in Neurobiology, 7, 217-227. http://dx.doi.org/10.1016/S09594388(97)80010-4

Nagel, T. (1974). What is it like to be a bat? The Philosophical Review, 83, 435-450. http://dx.doi .org/10.2307/2183914

Nagel, T. (2012). Mind \& cosmos: Why the materialist neo-Darwinian conception of nature is almost certainly wrong. Oxford, UK: Oxford University Press. http://dx.doi.org/10.1093/acprof:oso/ 9780199919758.001.0001

Nairne, J. S. (2005). The functionalist agenda in memory research. In A. F. Healy (Ed.), Experimental cognitive psychology and its applications: A Festschrift in honor of Lyle Bourne, Walter Kintsch and Thomas Landaur (pp. 115-126). Washington, DC: American Psychological Association. http://dx.doi.org/10.1037/10895-009

Nairne, J. S., \& Pandeirada, J. N. S. (2008). Forgetting. In H. L. Roediger (Ed.), Learning and Memory: A comprehensive reference (Vol. 2, pp. 179194). Oxford, UK: Elsevier. http://dx.doi.org/10 .1016/B978-012370509-9.00148-0

Neisser, U. (1981). Memory observed: Remembering in natural contexts. San Francisco, CA: Freeman and Company.

Newton-Smith, W. H. (1980). The structure of time. London, UK: Routledge \& Kegan Paul.

Papa-Grimaldi, A. (1998). Time and reality. Aldershot, UK: Ashgate.

Payne, D. G. (1987). Hypermnesia and reminiscence in recall: A historical and empirical review. Psychological Bulletin, 101, 5-27. http://dx.doi.org/10 .1037/0033-2909.101.1.5

Plato. (2002). A Plato reader: Eight essential dialogues. Indianapolis, IN: Hackett Publishing Company, Inc.

Polster, M. R., Nadel, L., \& Schacter, D. L. (1991). Cognitive neuroscience analyses of memory: A historical perspective. Journal of Cognitive Neuroscience, 3, 95-116. http://dx.doi.org/10.1162/ jocn.1991.3.2.95

Popper, K. R. (1994). Knowledge and the body-mind problem: In defense of interaction. New York, NY: Taylor \& Francis.

Prigatano, G. P., \& Schacter, D. L. (1991). Awareness of deficit after brain injury: Clinical and theoretical issues. Oxford, UK: Oxford University Press.
Quine, W. V. (1969). Ontological relativity and other essays. New York, NY: Columbia University Press. http://dx.doi.org/10.7312/quin92204

Ribot, T. (1882). Diseases of memory. New York, NY: D. Appleton and Company.

Rochelle, G. (1998). Behind time: The incoherence of McTaggart's atemporal replacement. Aldershot, UK: Ashgate.

Roediger, H. L., III, \& Challis, B. H. (1989). Hypermnesia: Improvements in recall with repeated testing. In C. Izawa (Ed.), Current issues in cognitive processes: The Tulane Symposium on cognition (pp. 175-199). Hillsdale, NJ: Erlbaum.

Roediger, H. L., III, Weinstein, Y., \& Agarwal, P. K. (2010). Forgetting: Preliminary considerations. In S. Della Sala (Ed.), Forgetting (pp. 1-22). New York, NY: Psychology Press.

Rosenbaum, R. S., Murphy, K. J., \& Rich, J. B. (2011). The amnesias. WIREs Cognitive Science, 3, 47-63.

Rubin, D. C. (1996). Remembering our past: Studies in autobiographical memory. Cambridge, UK: Cambridge University Press. http://dx.doi.org/10 .1017/CBO9780511527913

Russell, B. (1949). The analysis of mind. London, UK: George Allen \& Unwin Ltd. (Original work published 1921)

Russell, B. (1992). Theory of knowledge. New York, NY: Routledge. (Original work published 1913)

Russell, B. (1999). The problems of philosophy. Mineola, NY: Dover Publications. (Original work published 1912)

Saint Augustine of Hippo. (1997). The confessions: The works of Saint Augustine: A translation for the 21st century (M. Boulding, Trans.). New York, NY: New City Press.

Schacter, D. L. (2001). The seven sins of memory: How the mind forgets and remembers. Boston, MA: Houghton Mifflin.

Seddon, K. (1987). Time: A philosophical treatment. Kent, UK: Croom Helm Ltd.

Sherry, D. F., \& Schacter, D. L. (1987). The evolution of multiple memory systems. Psychological Review, 94, 439-454. http://dx.doi.org/10.1037/ 0033-295X.94.4.439

Sider, T. (2001). Four-dimensionalism: An ontology of persistence and time. Oxford, UK: Oxford University Press.

Siderits, M. (2019). Buddha. In (E. N. Zalta, Ed.), The Stanford encyclopedia of philosophy archive. Retrieved from https://plato.stanford.edu/archives/ spr2019/entries/buddha/

Spencer Brown, G. (1957). Probability and scientific inference. London, UK: Longmans, Green and Co.

Squire, L. R., \& Alvarez, P. (1995). Retrograde amnesia and memory consolidation: A neurobiological perspective. Current Opinion in Neurobiology, 
5, 169-177. http://dx.doi.org/10.1016/09594388(95)80023-9

Strawson, G. (2009). Mental reality (2nd ed.). Cambridge, MA: MIT Press. http://dx.doi.org/10.7551/ mitpress/9780262513104.001.0001

Talland, G. A., \& Waugh, N. C. (1969). The pathology of memory. San Francisco, CA: Academic Press.

Tallis, R. (2008). The enduring significance of Parmenides: Unthinkable thought. London, UK: Continuum International Publishing Group.

Tallis, R. (2017). Of time and lamentation. Newcastle upon Tyne, UK: Agenda Publishing. http://dx.doi .org/10.2307/j.ctv5cg85x

Thompson, C. P. (1982). Memory for unique personal events: The roommate study. Memory \& Cognition, 10, 324-332. http://dx.doi.org/10.3758/ BF03202424

Thompson, C. P., Herrmann, D. I., Brude, D., Read, J. D., Payne, D. G., \& Toglia, M. P. (1998). Autobiographical memory: Theoretical and applied perspectives. Mahwah, NJ: Erlbaum, Publishers.

Toulman, S., \& Goodfield, J. (1965). The discovery of time. Chicago, IL: University of Chicago Press.

Tulving, E. (1964). Intratrial and intertrial retention: Notes towards a theory of free recall verbal learning. Psychological Review, 71, 219-237. http://dx .doi.org/10.1037/h0043186

Tulving, E. (1974). Cue-dependent forgetting. American Scientist, 62, 74-82.

Tulving, E. (2005). Episodic memory and autonoesis: Uniquely human? In H. S. Terrace \& J. Metcalfe (Eds.), The missing link in cognition: Origins of self-reflective consciousness (pp. 3-56). Oxford, UK: Oxford University Press. http://dx.doi.org/10 .1093/acprof:oso/9780195161564.003.0001

Tulving, E., \& Thomson, D. M. (1973). Encoding specificity and retrieval processes in episodic memory. Psychological Review, 80, 352-373. http://dx.doi.org/10.1037/h0020071

Turetzky, P. (1998). Time. New York, NY: Routledge.

Underwood, B. J. (1966). Experimental psychology. New York, NY: Appleton-Century-Crofts.

Vallentine, J. W. (2002). Prelude to the Cambrian explosion. Annual Review of Earth and Planetary Sciences, 30, 285-306. http://dx.doi.org/10.1146/ annurev.earth.30.082901.092917

Vallentine, J. W. (2004). On the origin of phyla. Chicago, IL: University of Chicago Press.

Wallace, R. A. (2003). Choosing reality: A Buddhist view of physics and the mind. Ithaca, NY: Snow Lion Publications.

Walsh, V., \& Kulikowski, J. (1998). Perceptual constancy: Why things look as they do. Cambridge, UK: Cambridge University Press.

Whitehead, A. N. (1929). Process and reality. New York, NY: Macmillan.

Whitrow, J. G. (1980). The natural philosophy of time. Oxford, UK: Clarendon Press.

Williams, G. C. (1966). Adaptation and natural selection: A critique of some current evolutionary thought. Princeton, NJ: Princeton University Press.

Wixted, J. T. (2004). The psychology and neuroscience of forgetting. Annual Review of Psychology, 55, 235-269. http://dx.doi.org/10.1146/annurev .psych.55.090902.141555

Young, J. Z. (1976). The evolution of memory. Burlington, NC: Scientific Publications Division, Carolina Biological Supply Company.

Yourgrau, P. (2005). A world without time: The forgotten legacy of Godel and Einstein. New York, NY: Basic Books.

Received April 11, 2019

Revision received May 14, 2019

Accepted May 14, 2019 